\title{
Veronderstelt de natuur een plan en intelligentie? ${ }^{1}$
}

H M Vroom

(Vrije Universiteit, Amsterdam)

\section{ABSTRACT}

Does nature presuppose a plan and intelligence?

This contribution analyses the various domains of argumentation in the discussions on intelligent design and creation \& evolution: scientific facts, philosophical interpretations on nature and on divinity, and theological reflections upon the relation between and integration of such philosophical interpretations and the biblical message about God. If arguments from those domains are related to quickly, the argumentation becomes sloppy and conclusions are reached to hasty. Therefore the different domains have been distinguished carefully. The intelligence of natural laws points to an intelligent source. The complexity of progress in the evolutionary process suggests that it is improbable that it just has developed by change - whatever the consequences for the understanding of developments that can be valuated as good or as evil. In the last sections the relation between a philosophical idea of intelligence and creation and the biblical ideas of God as Creator, of the goodness of God, and the reality of evil are discussed.

\section{TER INLEIDING}

Een oud conflict—schepping en evolutie—is de laatste tijd weer tot leven gekomen door mensen die menen dat de vindingen van de natuurwetenschappen en evolutiebiologie een intelligente inrichting van de natuur laat zien. De evolutieleer wordt vaak tegen geloof in God ingebracht: de evolutie van de soorten kan worden verklaard uit mutaties en selectie: de best aangepaste soort overleeft de andere; door de buitengewoon lange tijdspanne vonden er voortdurend mutaties in het genetisch materiaal plaats die voor de verdere ontwikkeling van de soorten hebben gezorgd. Er worden heftige debatten gevoerd. Naast sterke voorstanders van "intelligent design"

1 Hierdie bydrae het oorspronklik gedien as ' $n$ lesing wat aan in Julie 2005 aan die Kangnam Universiteit in Korea en in Augustus 2006 aan die Universiteit van Pretoria gelewer is. Die outeur is ' $n$ navorsingsgenoot van Prof C J Wethmar in die Departement Dogmatiek en Christelike Etiek van die Fakulteit Teologie aan die Universiteit van Pretoria. 
zijn er geharnaste tegenstanders, die vinden dat de wetenschap beschrijft maar nooit of te nimmer uitspraken zou kunnen doen die naar een godsidee rieken.

Het debat over schepping en evolutie gaat uiteraard terug op Darwin en zijn tegenstanders. Na de Tweede Wereldoorlog was het boek van Jan Lever Creatie en Evolutie voor de Vrije Universiteit en de Gereformeerde Kerken een mile-stone. Eind jaren zestig verschenen onder redactie van C J Dippel en J M de Jong de twee bundels Geloof en Natuurwetenschap met beschouwingen waarin enerzijds de stand van relevante science werd beschreven en anderzijds grondige theologische doordenkingen van de resultaten van natuurwetenschappelijk onderzoek en de bijbelse visie op schepping en natuur ${ }^{2}$. De laatste jaren is de kwestie van "intelligent design" sterk in de aandacht gekomen. Natuuronderzoekers bepleiten dat de wetenschap eerlijk erkent dat de structuren van de natuur en verschijnselen uit de evolutie intelligentie verraden; aan de wereld ligt een intelligent plan ten grondslag, zo zegt men. Ronald Meester, Cees van Dijk en andere natuurwetenschappers en de filosoof René van Woudenberg gaven het debat in Nederland een impuls met hun bundel Schitterend ongeluk of sporen van ontwerp? (2005). Dat veel moslims moeite hebben met de naturalistische inslag van de evolutieleer draagt bij aan de actualiteit van het debat. Sommige wetenschappers verzetten zich er om methodologische redenen tegen: wetenschap dient levensbeschouwelijk onpartijdig te zijn en dus geen uitspraken voor of tegen een Godsidee te doen.

In dit boekje gaat het mij niet om een beschrijving van de huidige evolutieleer en de theologische literatuur die over de verhouding schepping en evolutie is verschenen. Mijn vraag is: hoe ga ik om met wat ik over deze discussies lees-op grond van de beperkte literatuur die ik erover kan lezen?

In deze discussie vind ik vooral twee dingen interessant. Ten eerste de verhouding tussen kennis van de natuur, kennis van het menselijk bestaan en kennis van God. Ten tweede de argumentatie in de discussie over de orde in de natuur en over "het ontstaan van de

2 Jan Lever (1958); Dippel (1965-1967), met prachtige beschouwingen waarin enerzijds de stand van relevante natuurwetenschappen werd beschreven en anderzijds theologische doordenkingen van de resultaten van natuurwetenschappelijk onderzoek en de bijbelse visie op schepping en natuur. 
soorten” in relatie tot levensbeschouwing. Ik licht beide punten kort toe en kom dan tot de vraagstelling van dit hoofdstuk.

Eerst iets over de verhouding tussen kennis van de natuur en kennis van God. Thomas van Aquino zegt dat de waarheden die de rede ontdekt de waarheden uit de openbaring niet kunnen tegenspreken, want beide zijn van God afkomstig (ScG I.7). Een christen kan de feiten van de natuurwetenschappen niet ontkennen. Wel moeten we nagaan welk godsbeeld er in de discussie geloofnatuurwetenschap wordt opgeroepen. Gaat het om een god van filosofen of om de God van de bijbel?- om met Theo de Boer te spreken (1989). In het spoor van Karl Barth maken mensen als Karel Deurloo en de zogenaamde Amsterdamse School er bezwaar tegen om in het christelijke spreken over God te beginnen bij de schepping, laat staan bij een godsbeeld dat aan de natuurlijke orde is ontleend. Is de natuurlijke theologie het vloertje voor het verbond of het verbond de grond van de schepping?-om het barthiaans te zeggen. Christelijke theologie moet 'in het midden' beginnen, in de geschiedeniservaringen van gelovigen, in plaats van aan een begin in de formules van de theoretische natuurkunde en astronomie?, zoals Ernst Beker en Karel Deurloo het hebben uitgedrukt (Beker 1977; vgl.Vroom 2007). Martin Heidegger heeft bezwaar aangetekend tegen een spreken over het goddelijke als een soort binnen-wereld zijnde; hij noemt dat dan ook onto-theologie ${ }^{3}$. Leidt de discussie of de orde in de natuur naar een intelligentie erachter verwijst, niet naar God als een binnen-wereldlijke ingenieur die de natuur slim heeft ontworpen? De vraag is dus bij wat voor godsbeeld de christelijke theologie via deze discussies terecht komt? Voor veel denkers uit deze richtingen is met dit bezwaar de kous af. Dat lijkt mij voorbarig, want als de structuur van de natuur en de voortgang van de evolutie intelligentie en een soort ontwerp zou verraden, kan men dat dan ontkennen op grond van een theologische of filosofische godsidee? Het lijkt mij niet redelijk om (echte) feiten te ontkennen als die niet in een wijsgerige of theologische visie passen.

Het tweede probleem dat die mij sterk interesseert ligt in het verlengde hiervan. In discussies en literatuur over schepping en evolutie treedt niet zelden een vermenging van soorten argumenten

3 Men ziet dan het onderscheid tussen zijn en zijnden niet, Martin Heidegger (1967:207v.; 1957). 
op. Auteurs springen soms over van natuurfilosofische redeneringen naar godsdienstwijsgerige of theologische argumenten zonder die overgang te verantwoorden. In dilemma's die natuurfilosofisch moeilijk beslisbaar zijn, geeft dan ineens een verwijzing naar het lijden in deze wereld de doorslag, zelfs zonder dat de auteurs de theodicee diepgaander bespreken. Kortom, ik verbaas me soms over de zwakte van de argumentatie-juist in het veld van geloof en wetenschap, waarin men striktere argumentatie zou verwachten. Het lijkt me erg belangrijk om de verschillende redeneringen goed te onderscheiden. Er is een natuurkundig en een biologisch discours naast een wijsgerige en theologische argumentatie. Mijn vraag is op welke manier argumenten en conclusies uit het ene wetenschapsgebied consequenties hebben op het andere. Ik heb al aangegeven dat een gelovige intellectueel dient te wijken voor echte feiten-maar uiteraard moet nagaan of "feiten" echte feiten zijn. Deze twee kwesties komen in dit hoofdstuk aan de orde.

\section{DE FYSISCHE EN CHEMISCHE ORDE IN DE NATUUR}

Wijsgerig gezien is één van de meest boeiende vragen rond het ontstaan van het universum die naar de wetmatigheden bij de Big Bang. Voorbeelden daarvan zijn fundamentele kenmerken van de huidige werkelijkheid, zoals de zwaartekracht en het periodiek systeem dat de mogelijke chemische verbindingen bepaalt. Gold de zwaartekracht op dat moment al of is die toen tot stand gekomen? Je kunt daar op drie manieren over denken, als een contingente of een noodzakelijke of een intelligente "oorzaak". Onder contingent verstaan we hier dat de oorzaak van de natuurwetten toevallig is: de zwaartekracht had anders kunnen zijn en er hadden andere chemische elementen kunnen ontstaan--het berust op zuiver toeval. Onder noodzakelijk verstaan we dat er vóór het ontstaan van het universum een constellatie was waaruit de ordening van de huidige fysische en chemische aspecten van de natuur causaal is voortgekomen: er kon niets anders ontstaan dan orde en wel de huidige, feitelijke orde. Als deze ordening niet contingent en ook niet noodzakelijk tot stand is gekomen, dan rest slechts dat die door een intelligent wezen tot stand is gebracht.

Ik vind dat deze vragen onderscheiden moeten worden van de evolutie, want hier gaat het niet om wat er binnen de natuurlijke ordening gebeurt maar om de natuurlijke orde zelf. Het feite dat er structuren zijn waarbinnen dan de soorten zich hebben ontwikkeld, 
is verwonderlijk op zichzelf, nog afgezien van hoe men de daarop volgende ontwikkeling beoordeelt.

\subsection{Natuurwetten onverklaarbaar?}

De eerste vraag is daarom die naar de voorwaarden voor elke evolutie: de fysische en chemische structuren die in de evolutie worden voorondersteld. De natuurfilosoof Paul Davies heeft de vraag naar de intelligente orde in de natuur nadrukkelijk aan de orde gesteld. "Can the Universe Create itself?", luidt het opschrift van een paragraaf van zijn boek, The Mind of God (1993:39-72). Het gaat om de regelmatigheden die aan gebeurtenissen in het universum ten grondslag liggen - de natuurwettelijke ruimte waarbinnen fysische, chemische, biologische en historische ontwikkelingen mogelijk waren. Deze vraag ligt buiten de empirische wetenschap; beschrijvend wetenschappelijk onderzoek beschrijft natuurlijke processen en leidt daar de natuurwetmatigheden uit af die deze processen mogelijk maken en verklaren. Conform de traditionele wetenschapsleer betekent verklaren dan dat men laat zien dat natuurlijke processen zich volgens wetmatigheden voordoen. Men kan zelf uit de 'Big Bang' terug proberen te redeneren om uit te zoeken welke wetmatigheden de 'Big Bang' vooronderstelde. Maar wat beschrijvend onderzoek op basis van waarnemingen niet kan, is vaststellen waar deze wetmatigheden zelf vandaan komen. De vraag naar de verklaring voor het verwonderlijke feit dat er natuurwetmatigheden bestaan ligt niet op empirisch vlak maar op het gebied van de bezinning op natuur en natuurwetenschap, en is dus een vraag uit de filosofie van de natuur en natuurwetenschap. Welnu, hiermee keren we terug naar de drie soorten verklaringen voor de wetmatigheden die geordende natuur mogelijk maken.

De eerste mogelijkheid-de natuurwetten zijn contingent ontstaan-is aantrekkelijk voor atheïsten en sceptici. De zwakte van deze opvatting is dat men een vaste wetmatigheid verklaart uit een overgang van iets chaotisch en niet-intelligents naar een intelligente orde. Paul Davies meent dat het universum zelf creatief is en de eigenschappen als eenvoud, schoonheid en ingenuïteit heeft, en dat heel de huidige werkelijkheid binnen de wetmatigheden zelf zijn voortgebracht. De regels lijken alsof ze het product zijn van een intelligent plan, maar het kan heel goed zijn dat het universum zelf deze transcendente eigenschappen bezit. Davies wil dus van een bedoeling spreken achter een wereld met intelligente mensen die 
intelligente natuur begrijpen als uitkomst zonder een godsbegrip in te voeren ${ }^{4}$. Dat lijkt mij een incoherente opvatting, omdat de notie van "plan" ondenkbaar is zonder iemand die een plan ontwikkeld.

Er is een fysische ordening die in wiskundige formules vatbaar is-formules die onderzoekers kunnen begrijpen. Het vaste patroon van deze intelligente ordelijkheid pleit niet voor een toevallig, onbedoeld (Van Woudenberg 2002:20v.), ontstaan van natuurwetten uit een chaos van toevallige processen-je kunt niet eens van een proces spreken als er geen orde is. Die overgang is on-denkbaar. Daarom ontkomt men niet aan de tweede mogelijkheid.

De tweede mogelijkheid is dat de intelligente ordening uit een eerdere ordening is ontstaan. Deze redenering loopt erop vast dat het probleem simpelweg wordt verschoven. Men postuleert een andere, eerdere of hogere ordening die de huidige causaal heeft voortgebracht. Men heeft daarvoor geen empirische aanknopingspunten, maar alleen de levensbeschouwelijke vooronderstelling dat iets causaals uit iets causaals voortkomt en dat er geen "oorzaak" van buiten het natuurlijke proces is. Deze redenering berust dus op een petitio principii: men moet bewijst dat $\mathrm{B}$ causaal uit $\mathrm{A}$ is voortgekomen, met de bewering dat iets als $\mathrm{B}$ altijd uit iets als A voortkomt. Deze redenering lost niets op. Dan kan men beter toegeven dat er geen wetenschappelijke verklaring bestaat voor de wetmatigheden in de wereld die fysische en chemische processen volgen. Vervolgens weigert men dan simpelweg de filosofische vraag te stellen of men deze ordening kan verklaren. Er bestaan levensbeschouwelijke stromingen die zeggen dat het universum eeuwig is, zodat de natuurwetten er altijd al zijn geweest. Het nadeel van deze kosmische levensbeschouwingen-die extreme transcendentie ontkennen: er is niets buiten dit universum - is dat ze toch moeten onderscheiden tussen de eenheid van het proces en wat zich daarbinnen voordoet ${ }^{5}$.

De derde van de drie mogelijke verklaringen van de ordelijkheid in fysica en chemie is dat zij uit intelligentie voortkomt.

4 Paul Davies (1993:214v.): “Is het universum absurd?”, 15; 17: het universum worde gezien "als de coherente, rationele, elegante en harmonieuze uitdrukking van een diep en betekenisvol doel”.

5 Dat lijkt me het probleem in Kitaro Nishida's (1990:79v) behandeling van immanente transcendentie. 
Aan het gebruik van 'intelligentie' hangt een prijskaartje. Intelligentie vereist minimaal bewustzijn. Ik kom daarop terug. Met deze stap verklaart men dus intelligente ordening. Het argument voor deze stap is dus dat de natuurwetten een ordening zijn. De idee van ordening vereist denken, het vermogen wetten vast te stellen en de wil een voornemen uit te voeren: intelligentie, vermogens en wil.

Deze derde mogelijkheid voor de natuurfilosofie om ordeningen te "verklaren" is veel meer plausibel dan de vorige twee "oplossingen", maar stelt voor het probleem dat men de stap zet vanuit de wetmatigheid van de natuur naar iets buiten de natuur, een Bedenker. In het denken over het feit dat er natuurwetmatigheden bestaan, stapt men dus over naar godsleer. In de uitwerking van de godsleer zal men terughoudend moeten zijn om niet meer over God te zeggen dan men uit deze gegevens kan afleiden. Bovendien rijst onvermijdelijk de vraag hoe men het bestaan van kan God verklaren. Mij lijkt de onverklaarbaarheid van God echter van een andere orde dan de onverklaarbaarheid van God. In het begrip “God” ligt volgens alle religieuze filosofieën immers begrepen dat God van een andere orde is dan de natuur (in brede zin) en dat de mens de oorsprong van God niet kan doorgronden. Het is ongerijmd om alle natuurlijke processen uit wetmatigheden te verklaren en dan het denken stop te zetten bij de vraag naar de verklaring voor intelligibele natuurwetten. Ik vind dat Paul Davies c.s. op dit punt het gelijk aan hun zijde hebben (1993:214v.; Dembski 1999 is nog stelliger).

Men kan hier tegenwerpen dat de wetenschap zulke vragen mag stellen. Wetenschap beschrijft en kan niet over God spreken, want "God" onttrekt zich aan empirisch onderzoek. Dat is juist, maar dat was de vraag niet. De vraag is of de filosofie van de natuur zich buigt over de herkomst van ordeningen en de vraag of ordeningen "spontaan" uit louter chaos kunnen ontstaan. Als de filosofie van de natuur op dit punt over God komt te spreken, dan vindt ze onmiddellijk een gesprekspartner in de wijsgerige en theologische godsleer. Het zou buitengewoon merkwaardig zijn als de ene tak van filosofie niet met de analyses in andere takken van wijsbegeerte zou rekenen. Als natuurfilosofie zou stellen dat de godsidee de beste verklaring voor wetmatigheden in het universum zou zijn, dan moet de wijsgerige godsleer daarmee rekenen en moeten theologische geloofsdoordenkingen de consequenties voor hun religie doordenken. 


\subsection{Vragen die verder gaan...}

Als men nu tegenwerpt dat de natuurfilosofie niet verder kan gaan dan de constatering dat er een "diepere onderliggende bedoeling is" (Davies 1998:14) en het daarbij wil laten, dan wil ik op drie wijsgerige discussies wijzen waarin de filosoof gedwongen is om een grondvraag op ander niveau te stellen.

Voor de stap van de ordening naar een ruimer kader dat moeilijk precies valt aan te geven en waarvoor harde bewijzen ontbreken wil ik op drie analogieën op andere gebieden van wijsbegeerte wijzen. In de empiristische kenleer had men het verificatiebeginsel—alle kennis komt uit waarnemingen—, maar het verificatiebeginsel kwam zelf niet uit waarnemingen voort. In het vorige hoofdstuk bracht ik dit punt al ter sprake: is het criterium voor wat als kennis kan gelden, zelf geldige kennis? Het vaststellen van sluitende criteria voor geldige kennis is een beperking van het gebied van geldige kennis. Deze beperking kan men alleen rechtvaardigen door een overgang eis allos genos (naar een ander soort), de visie op kennis in een ruimer verband. Men werkt dus op twee niveaus. Het tweede voorbeeld is de fundering van de ethiek: de vraag 'why being moral?' kan niet aan de hand van inhoudelijke morele geboden worden beantwoord en wijst dus boven de ethiek uit. Ten derde, een andersoortig beroep op twee niveaus' vinden we in het zelfbewustzijn: dat is de reflectie op zichzelf van een mens die tegelijk als geheel zichzelf is. Dit 'in mij met mezelf' blijft een raadsel: men veronderstelt een eenheid in de onderscheidenheid van een zelf dat zich-zelf bewust is. De eenheid van feitelijk zelf en reflexiviteit valt, denk ik, ook buiten het empirisch vaststelbare. In sociologisch onderzoek kan men vaststellen welke criteria mensen feitelijk willen hanteren, waarom mensen naar hun zeggen moraal willen zijn of niet en hoe mensen hun identiteit en zelf-bewustzijn beleven, maar de wijsgerige vraag blijft dan of hun ideeën begrijpelijk en verdedigbaar zijn. Die vraag gaat de vaststelbare feiten te boven. Kortom, op meer gebieden van wijsbegeerte liggen funderingen en dieper begrip buiten de empirisch vaststelbare feiten. Omdat deze doordenking uitgaat van feiten en ermee moet rekenen, blijft zij op het terrein van redelijk denken.

\subsection{Is orde gemaakt?}

Dat geldt ook van de doordenking van de mogelijkheidsvoorwaarden van de natuurlijke orde. Al stelt de godsleer zelf voor ingrijpende 
vragen, toch lijkt het mij redelijker om de wetmatigheden in de natuur uit intelligentie te verklaren dan uit toevallig ontstaan uit chaos of de vraag door te schuiven naar een eerdere of eeuwige ordening. Het argument is dat een ordelijke, intelligente ordening niet uit chaos, toeval en iets niet-intelligents kan voortkomen. Daarmee staan we voor de vraag of de fysische orde naar een schepper wijst.

Wijsgerige bezinning op een intelligente natuurlijke wetmatigheid, die niet toevallig kan zijn ontstaan, leidt voorzover ik vermag te zien dus naar de idee van een Maker. In de concepten "maken" en "intelligentie" ligt meer besloten, namelijk de mogelijkheid om zich een doel te stellen, overzicht, inzicht, de macht iets te plannen en te maken, en wil om het één wel en het ander niet te verwezenlijken. Als voorbeeld van een dergelijke visie citeert Paul Davies een hymne van Kempthorn uit 1796 over God als de maker van de natuurwetten:

Praise the Lord! for He hath spoken

Worlds his mighty voice obeyed

Laws, which never shall be broken

For their guidance He hath made (Davies 1993:85v).

Zoals gezegd, zijn de wiskundig formuleerbare wetmatigheden in de natuur voor Davies reden om een intelligente planmatigheid in en van het universum te postuleren, zonder de stap naar een godsidee te zetten-hij neemt afstand van een theïstisch godsbegrip. Het is juist om in filosofische bezinning op wetmatigheid in de natuur terughoudend te zijn ten aanzien van religieus spreken over God. Maar, zoals ik al eerder opgemerkte, het is niet terecht om alleen van intelligentie te spreken en niet van plan, wil en vermogen een voornemen te realiseren.

Als men wel met het bovenstaande instemt, rijzen er drie vragen. De eerste is in hoeverre er bij de natuurlijke orde van Design sprake is. In beperkte zin lijkt me dat het geval. Enerzijds is er een ordening die is ontworpen en waarbinnen ontwikkelingen mogelijk zijn, anderzijds gaat het niet over evolutie en contingente of nietcontingente ontwikkelingen binnen het geschapen kader. De tweede vraag is of dit een godsbewijs is. Het antwoord lijkt mij niet zo moeilijk: het is geen wetenschappelijk bewijs want het treedt buiten de empirische wetenschap, maar het is wel een zinnige redenering en in die zin een argument om het spreken over een Maker van het 
universum serieus te nemen. De derde kwestie is de relatie van deze Maker van de natuurwetten tot een bijbels godsbeeld-dat geldt ook de islam, lijkt mij. Ten eerste moeten we de psalmen en andere gedeelten uit de bijbel en vele teksten in de Koran verdisconteren die God loven als Maker van de natuur. "Zijn onzichtbare eigenschappen zijn vanaf de schepping van de wereld zichtbaar in zijn werken, zijn eeuwige kracht en goddelijkheid zijn voor het verstand waarneembaar...” (Romeinen 1:20)—lijkt mij een woord dat nog steeds zijn geldigheid behoudt blijft de vraag bestaan hoe dit godsbeeld zich verhoudt tot hoe God in de bijbel verder wordt getekend. Dat de ordening in de wereld naar God verwijst betekent niet dat andere godskennis uit de bijbel bijkomstig is.

Men lette erop dat de argumentatie tot dusverre niet raakt aan de evolutie en ook niet aan de goedheid en wreedheid in de natuur. Daarom vind ik het niet zo gemakkelijk om bij dit godsbeeld over de goedheid van God te spreken. Velen van ons zijn tegenwoordig sterk onder de indruk van het lijden dat veel mensen overkomt. Voor een deel ligt de oorzaak bij mensen, maar daarmee is niet alles verklaard. De menselijke beperkingen en zwakheden zijn met het mens-zijn gegeven; aardbevingen, hongersnoden, droogten en overstromingen, kindersterfte en kanker-ze hebben niet of niet alleen menselijke oorzaken. In voorbije eeuwen hebben mensen God vaak geprezen om de oogst en de schoonheid van de natuur, maar in onze tijd is dat wel "toeristentheologie" genoemd: zolang de zon schijnt en we geen wreedheden zien, vinden we het prachtig (De Boer 1989:94).

\section{EVOLUTIE}

Na een bespreking van een natuurlijke orde die een plan suggereert, volgt uiteraard de vraag of de evolutie die door die orde mogelijk wordt gemaakt ook een doel verraadt. Daarmee staan we voor de vragen rond de evolutie.

Evolutie speelt zich af binnen de structuur van de fysische en chemische orde die we hebben beschreven. Dat geldt ook al van geologische ontwikkelingen, die zowel aanslibbing van vruchtbare vlakten en aardbevingen, regen en zonneschijn, droogte en nattigheid hebben voortgebracht. De invulling van de werkelijkheid binnen de natuurlijke orde brengt ons bij biologische en culturele ontwikkelingen: evolutie en geschiedenis. De vraag hoe men het ontstaan der soorten kan verklaren is een andere dan de vraag naar 
het ontstaan van de mens en de gang van de geschiedenis. Natuurlijke historie verschilt van wereldgeschiedenis.

Bij analyse van de argumentatie is het uitgangspunt uiteraard weer dat biologische feiten niet hetzelfde zijn als opvattingen in de filosofie van de biologie. Zolang de empirische feiten geen sluitend bewijs leveren, geven levensbeschouwelijke visies de doorslagzowel bij ongelovigen als bij gelovigen. Bij de interpretatie van de feiten speelt levensbeschouwing al een rol; het is zaak vaststaande feiten goed te onderscheiden van interpretaties die door een visie op het leven worden ingegeven. Ideeën over evolutie zijn mengsels van feiten en interpretaties op grond van levensbeschouwelijke veronderstellingen.

\subsection{Mutaties en "survival of the fittest"}

De wetenschappelijk evolutietheorie kan niet buiten de empirische feiten treden-dat is haar eer en zekerheid. Terecht denkt men erover na of alle soorten levende natuur uit contingente mutaties en "survival of the fittest"-de twee principes van de klassieke evolutietheorie-kunnen zijn ontstaan. Het wetenschapstheoretische probleem is dat theorieën over bruikbare mutaties en het overleven van de meest aangepaste gemuteerde exemplaren niet experimenteel kunnen worden getoetst. Het blijven theorieën met veel minder "hardheid" dan wiskundige formuleringen van natuurwetten en chemische reacties. Niettemin zijn er meer dan voldoende aanwijzingen dat de opeenvolging van soorten een grote rol speelt in de ontwikkeling van de natuur en de mensheid. Of men precies weet hoe het gegaan is en daarvoor voldoende bewijzen heeft is meer dan twijfelachtig. In wat volgt beschrijf ik kort enkele elementen uit de discussie rond evolutie. Het gaat hier immers niet om de exposé van feiten-dat men bij biologen kan vinden-maar om de manier waarop men er als christen redelijk mee kan omgaan.

Simpele voorbeelden van het nut van mutaties voor het overleven van een (beter aangepaste) soort zijn bekend genoeg; ik vermeld er één: de mutant zwarte vlinder in de Engelse mijnstreek overleefde terwijl diens witte voorouders door de vogels gemakkelijker werden gevonden en opgegeten. Dat is contextuele "survival of the fittest". Natuurdocumentaires bezwijken veelvuldig voor de verleiding om de natuur als persoon voor te stellen: de Natuur heeft dit beest deze en dat beest die eigenschappen meegeven om te overleven. De Natuur wordt hier als een actor met een 
bedoeling voorgesteld. Zalmen uit de Stille Oceaan weten waar ze in Alaska moeten paaien voor ze daar uitgeput dood gaan; de Natuur heeft hun dat meegegeven. Maar laten we de bedoelingen van de natuur maar vergeten en ons aan feiten houden: De wonderen der natuur worden causaal verklaard via mutatieprocessen die contextuele aanpassingen mogelijk maken en nieuwe soorten met hogere complexiteit zouden voortbrengen. Op dit punt moet men onderscheiden tussen contextueel bruikbare, toevallige mutaties en het ontstaan van ingewikkelder soorten. Het laatste is moeilijker verklaarbaar dan het eerste, want daarbij gaat het om het ontstaan van ingewikkelder eiwitverbindingen, de overgang van levenloze naar levende natuur, de overgang van eencelligen naar meer-celligen, de ontwikkeling van ingewikkelde functies en het ontstaan van vernuftige organen met steeds specifieker functies en uiteindelijk van bewustzijn en zelfs zelfbewustzijn ${ }^{6}$.

Het kernprobleem voor een strikt-causale verklaring van de evolutie is de verklaring van toevallige processen binnen een causaal vastliggende structuur van de natuur die aan steeds ingewikkelder structuren voorafgaan. Het woord "voortbrengen" zou hier te veel zeggen, want de later ontstane, meer complexe structuur van ingewikkelder soorten vergt niet een maar vele mutaties tegelijkertijd-een mogelijkheid die niet empirisch kan worden aangetoond tenzij die zich morgen ergens in de wereld voordoet en degelijk onderzocht kan worden. Uiteraard is het een taak van de biologie om na te gaan of die ketens van oorzakelijkheid en de continuïteit in de ontwikkeling van complexer wezens uit minder complexe kan worden aangetoond.

Ik denk dat we van de volgende inzichten moeten uitgaan:

(1) de ontwikkeling en uitwaaiering der soorten kent de één of andere natuur-historische samenhang;

(2) na elkaar, is niet hetzelfde als: het latere is veroorzaakt door het eerdere $^{7}$;

6 Vgl. een opsomming van zaken die in de evolutietheorie volgens Demski (1999:111) onverklaard blijven, Zie Mart de Groot (2005:190-193).

7 Dat was het grote punt van David Hume, dan Kant op de gedachte bracht dat het bouwwerk van onze kennis op zintuiglijke indrukken berust, die door het verstand worden geordend. Bij ons onderwerp is het belangrijk om niet te 
(3) een genetische verandering die maakt dat in een soort één eigenschap verandert (zoals van wit naar zwart) niet hetzelfde is als een verandering van een soort tot een complexer soort.

Vanwege (3) is bij elke stap in de evolutie te bewijzen dat er een redelijke kans is dat een dergelijke verandering als gevolg van spontane mutaties optreedt. Gegeven de uiterst kleine kansen op zinvolle mutaties, en de complexiteit van ingewikkelder vormen van levende wezen blijft het ontstaan van complexer wezens een duistere plek in wetenschappelijke verklaringen. De evolutietheorie is een waardevolle en overtuigende biologische theorie, die laat zien dat de soorten elkaar 'opvolgen' maar op dit moment niet sluitend verklaart hoe dat gebeurt en dus ook niet dat het proces een zuiver causaalcontingent proces is.

\subsection{De duiding}

Hiermee staan we voor de vraag hoe deze onverklaarbare gegevens in de evolutie wijsgerig moeten worden geduid. Ten eerste, het is duidelijk dat de empirische wetenschap niet boven de feiten uitgaat. Onderzoekers dienen te onderzoeken of men de 'gaten' in de evolutie met nieuwe vondsten kan opvullen en of toenemende complexiteit en merkwaardige analoge ontwikkelingen in verschillende soorten levende wezens empirisch kunnen worden verklaard. In de filosofie van de biologie moet men nagaan of de methodologie van de evolutietheorie zuiver is en welke levensbeschouwelijk relevante stellingen over het ontstaan van het leven en de soorten wel en niet uit empirisch onderzoek voortvloeien. Waar leemten in het onderzoek bestaan die men niet empirisch kan oplossen, is elke verdere conclusie levensbeschouwelijk van aard. Een naturalist zal beweren dat nader onderzoek zal aantonen dat de hele ontwikkeling contingent-causaal is, maar daarmee gaat hij wel ver boven de feiten uit.

Een gelovige kan beweren dat God de ontwikkeling van de schepping leidt, maar als men dat doet moet men ook schijnbaar zinloze ontwikkelingen en leed als onderdelen van Gods plan doordenken. Zowel een naturalist als een gelovige staan voor ingrijpende vragen.

snel van "B volgt op A” tot “A veroorzaakt B” te concluderen. Daarvoor zijn meer argumenten nodig. 


\section{METHODISCHE OVERWEGINGEN}

De stap van de "feiten" naar een levensbeschouwelijke stellingname wordt vaak te vlug gezet. We moeten verschillende vakgebieden onderscheiden die ook uiteenlopende expertise vergen:

a) empirisch onderzoek;

b) theoretische reflectie op onderzoek (daaronder vallen de formulering van natuurwetten, het periodiek systeem en een ordening van gegevens inzake evolutie);

c) filosofische doordenking van de mogelijkheidsvoorwaarden van natuurwetten en evolutie-die leidt tot het aangeven van interpretatie-mogelijkheden;

d) theologisch-wijsgerige doordenking van de filosofische interpretatiemogelijkheden in een bredere context.

In feite is een wisselwerking tussen deze verschillende lagen in onderzoek en reflectie noodzakelijk. Daarbij zal "het gesprek" tussen a) en b) een andere expertise vergen dan "het gesprek tussen" b) en c), en dat tussen c) en d). Naturalistische en theïstische levensbeschouwingen spelen pas op niveau c) en expliciet op niveau d).

Als men deze niveau's niet uit elkaar houdt, vervuilt men de argumentatie en trekt men voorbarige conclusies. Als men zich tot één niveau beperkt, moet men ervoor zorgen dat uitspraken tot dat niveau beperkt blijven.

Voorbeelden daarvan verwijzingen naar Gods goedheid die onmogelijk lijden kan hebben toegelaten of naar de moeilijkheid om handelen van God te verbinden met een proces van mutaties en ontwikkeling van de soorten of, aan de andere kant, de afwijzing van een godsidee.

Men kan zeggen dat een biologische evolutietheorie een gebrekkige theorie is als die niet sluitend is, maar als denkend mens kan men die niet afwijzen omdat men vindt dat die moeilijk met zijn levensbeschouwing te verbinden is. Net zo min kan een ongelovige de onverklaarde overgangen in de evolutie met naturalistische dogma's afdoen. Ieder moet zich aan de feiten houden.

Het voorafgaande betekent volgens mij dat de orde in de natuur de idee van planning oproept. De evolutie der soorten maakt het ontstaan van leven en allerlei levende wezens en menselijk 
bewustzijn tot een verwonderlijk feit dat om verdere reflectie vraagt_zeker als de toename van complexiteit binnen het kader van empirisch onderzoek niet te verklaren valt. De idee van intelligentie en sturing dringt zich ook hier op. Tegelijk moeten we bedenken dat die sturing niet concreet valt aan te wijzen. Ook de vraag of men hier van de goedheid van God of van "de Natuur" kan spreken, is lastig, want de wereld kent naast veel moois en goeds ook veel mislukking en fysisch kwaad. (Waarom heeft "de Natuur" het ene dier iets wel meegegeven en het andere niet?) Met andere woorden, uit deze overwegingen kan men slechts een aantal eigenschappen van God afleiden-zoals die we al opsomden-, maar niet of God goed en rechtvaardig is. Om over die eigenschappen van God te spreken, moet men er ook de mensenwereld, de geschiedenis en de religie in betrekken.

\section{SCHEPPING}

Met veel moeite heeft een groot deel van de kerken sinds 1950 afscheid genomen van de idee dat Genesis 1-9 een beschrijving is van de exacte gang van zaken in de schepping en de oergeschiedenis van de mensheid. Daardoor kwam de weg vrij voor onderzoek naar de bedoelingen van Genesis 1 in de context waarin de tekst is ontstaan $^{8}$. Het werd steeds duidelijker dat het geen mythe is in de zin van een godenverhaal, maar een volstrekt doordachte theologie in narratieve vorm, waarbij de vorm van een verhaal de mogelijkheid biedt om paradoxen en symbolische uitdrukkingen te laten bestaan, die de lezer tot mediteren uitdagen. Een enkel voorbeeld. Eerst wordt het licht geschapen, dan de zon. In het paradijs staat de boom van kennis van goed en kwaad; het kwaad is beperkt tot één ding: overtreding van dit ene gebod en dus ongehoorzaamheid aan God. Als de mens van deze boom eet, wordt de mens gelijk aan God, wetend van goed en kwaad. Wat het is om te weten van goed en kwaad, blijft betrekkelijk duister en de uitleg ervan is eerder wijsbegeerte in de echte zin van het woord dan exegese: gedachten vermengen zich met ervaringen en verbreden zich tot meditaties over de plaats van God en mens in een wereld van geluk en ongeluk, recht en onrecht. De verhalen over de schepping, het paradijs, de zondeval en de eerste moord zijn narratieve theologie in strenge zin:

8 Vgl. recent over de mens als imago dei, Middleton (2005); Van Huyssteen (2006:111-162). 
doordachte verhalen met een hogere graad van complexiteit dan strakke redeneringen. Om dat weer te leren zien, moest de Westerse theologie haar aristotelische, scholastieke en sciëntistische ballast overboord zetten. Het scheppingsverhaal staat in de context van de Mesopotamische cultuur met zijn strakke hiërarchie en schrijnende ongelijkheid van mensen (Middleton 2005:147-231).

Dit betekent dat een theologische scheppingsleer vanuit de bijbel niet primair betrokken is op hoe de wereld fysisch en biologisch gezien tot stand is gekomen, maar op de bedoelingen van God. De feiten uit de evolutietheorie gaan over het "empirische hoe" van het ontstaan van deze wereld maar kunnen het achterliggende “waarom?"en "hoe?” niet verklaren-en juist dat is waar het in de bijbelse visie over gaat.

\section{CONCLUDERENDE BESCHOUWINGEN}

Ik kom tot enkele concluderende beschouwingen: over de verhouding van natuuronderzoek en theologie, schepping en evolutie en de verhouding tussen de God van de natuurlijke orde en het bijbelse godsbeeld.

\subsection{Onderzoek van de natuur-bezinning op de wereld als schepping}

Men zegt soms dat het twee verschillende manieren zijn om naar dezelfde werkelijkheid te kijken. Dat is m.i. niet precies, want dan stelt men ze naast elkaar en dan is niet meer duidelijk dat empirische feiten gevolgen hebben voor de christelijke visie op de schepping. De (echte) feiten hebben het christelijke denken beïnvloed, en terecht. Ik zou dus liever niet zeggen dat het twee verschillende perspectieven zijn, maar dat het één fundamenteel en empirisch onderzoek is in de astronomie, de theoretische natuurkunde, de paleontologie en de biologie, en het ander exegetisch-historisch en systematisch theologisch onderzoek naar bijbelse ideeën en christelijke scheppingsleer. Het eerste gaat om een beschrijving van de wetmatigheden in de natuur en de ontwikkeling van de soorten, het tweede, theologische, om oorsprong van de wereld en de soorten en hun doel. In evolutie-onderzoek gaat het, als men het heel precies neemt, dus niet om The Origin of Species, maar om de feitelijke ontwikkeling ervan.

Dit betekent dat de verhouding tussen de natuurlijke orde en de evolutie-schepping geen parallelschikking is (zoals het lijkt in de 
uitdrukking "twee verschillende perspectieven"), maar dat ze zich verhouden als beschrijving van empirische feiten en een christelijke (en joodse en islamitische) doordenking van een visie op de omvattende werkelijkheid waarvan deze feiten deel uitmaken. Daarom staan ze niet los naast elkaar. De filosofie van de natuurwetenschappen, de wijsgerige theologie en de dogmatiek raken elkaar direct.

In zijn studie over de eerste mensen heeft Wentzel van Huyssteen hierop veel nadruk gelegd. Hij heeft zich uitvoerig verdiept in de paleo-ontologie. In de paleo-antropologie gaat het om wat de eerste mensen onderscheidde van hun directe voorgangers, de hominiden-apen met menselijke trekken. De christelijke theologie heeft in de reflectie op het speciaal-menselijke steeds nagedacht over wat de mens tot mens maakt. Dat de mens beeld is van God is daarbij een centrale uitdrukking worden. Van Huyssteen zegt met nadruk dat de resultaten van de paleo-ontologie van belang zijn voor de filosofie en de theologie, en omgekeerd ook de discussies in theologie en filosofie de paleo-ontologie kunnen helpen (2006:1024, 299-307). Wat de eerste "moderne" mensen van hun directe voorgangers-met vrijwel dezelfde biologische uitrustingonderscheidt, was dat ze taal spraken, symbolen gebruikten, zich bewust waren van de betekenis van dingen, en wat ze geleerd hadden in nieuwe situaties creatief konden toepassen (ibid. 234v.).

\subsection{Schepping en evolutie}

Als het om Design gaat moet men m.i. eerst naar de natuurlijke orde kijken. Die verraadt intelligentie. In de evolutie blijven met name toenemende complexiteit die in sprongen is ontstaan en de parallelle ontwikkelingen in verschillende takken van de evolutie van de soorten onverklaard, terwijl sommige ontwikkelingen beter uit doelgerichtheid dan uit toevallige causale gebeurtenissen kunnen worden verklaard (zie Susenbach 2005:134-143).

De natuurlijke orde en de "sprongen" in de evolutie ondersteunen de gedachte aan een goddelijke oorsprong van de schepping. Deze constatering sluit naar mijn mening aan bij de bijbelse verwondering over de schepping die psalmisten en profeten ertoe tot de erkenning van de grootheid van God heeft gebracht. De verwijzing naar God kan nooit een onderdeel worden van een natuurwetenschappelijke theorie of van de evolutie-theorie, tenzij men in staat zou zijn ingrijpen van godswege empirisch vast te 
stellen. Omdat dit onmogelijk is, valt de verwijzing naar God buiten de empirische wetenschap. Ook in de theologie kan men God niet narekenen. Daarvoor klinkt de verzuchting van de Prediker te luid: "Niemand kan het godsbestuur doorgronden".

\subsection{De God van de natuurlijke orde}

Paul Davies en anderen spreken terecht van intelligentie. Daar zit een breder godsbeeld aan vast dan Davies als natuurfilosoof waar wil hebben. Hij zoekt geen aansluiting bij religie. Enerzijds is dat sterk, anderzijds leidt het tot een zwakte in zijn visie. In The Mind of God spreekt hij er zijn verbazing over uit dat aan het eind van de evolutie een wezen is ontstaan dat in staat is de gang van de evolutie te beschrijven en de natuurwetten te ontcijferen. Met andere woorden, theoretische natuurkunde is geen toevalligheid en dus bedoeld: "we are meant to be” (Davies 1993:232).

Dit is een ruiterlijke erkenning dat de schepping een wonder is waarachter men bedoelingen moet vermoeden die met instrumenten niet kunnen worden onderzocht. Echter, wijsgerige godsleer is een exacter vak dan men vaak denkt. Het kwam al aan de orde: de idee van een intelligentie achter de natuurwetten en achter de evolutie vereist een lange reeks eigenschappen van God: wil, combinatievermogen, een vooruitziende blik, vermogen om plannen te smeden en lijnen uit te zetten, de macht om doelstellingen te verwezenlijken en het vermogen om als denkend goddelijk wezen een wereldse werkelijkheid te "maken". Wie aan God al deze eigenschappen toeschrijft, kan moeilijk blijven staan bij Davies' constatering dat "we", theoretische fysici en evolutiebiologen, zijn bedoeld als uitkomst van dit hele proces. De rest van de mensheid zou dan slechts zijn bedoeld om deze scherpe geesten voort te brengen. Dit is een merkwaardige versmalling in de reflectie op de doelen van wetmatigheid en evolutie. Toch zou men Paul Davies kunnen bijvallen als hij zich terughoudender zou opstellen en de grenzen van de natuurfilosofie zou aangeven door te zeggen: "tot zover kan de natuurfilosofie gaan: er moet een intelligent plan aan de natuurlijke orde ten grondslag liggen en ook de evolutie roept vragen op die door het bestaan van een intelligent en machtig wezen misschien beantwoord zouden kunnen worden."

Wat kan een christen daarop antwoorden? Zullen we met de psalmist zeggen: "Maar deze God is onze God" of moeten we zeggen: “de goden der volkeren zijn afgoden, maar onze God heeft 
de wereld gemaakt"? Op dit punt raken we aan de eeuwenoude discussie over godsbewijzen en de verhouding tussen de god der filosofen en de God van Abraham. De wetmatigheden in de natuur, de wonderlijke "fine-tuning" in de wereld (Davies 1993:204v.; Wintermans 2005:155v.; De Groot 205:189) en de enorme toename in complexiteit in levende wezens vormen geen godsbewijs, maar ze bewijzen wel dat de vraag naar God een redelijke vraag is. Mijns inziens is de idee van een Schepper plausibeler dan de idee dat de fysische en biologische werkelijkheid een zuiver causaal en in zich gesloten proces is. Deze constatering kan de theologie m.i. goed overnemen. Voor veel mensen is de ervaring van de schoonheid en verwonderlijkheid in de natuur een van de ervaringen die hun geloof dragen. Zij ervaren "schepping"-maar dat is direct al meer omvattend dan natuurwetten en evolutie.

De relatie tussen het hiermee gegeven godsbeeld en het volle bijbelse godsbeeld loopt parallel aan die tussen de natuurwetenschappelijke en de theologische beschouwing van de werkelijkheid. De bijbel spreekt ruimer en breder over God. Om het heel kort te zeggen; de schepping die oplicht in het onderzoek van de natuur verkondigt de grootheid en macht van God, de bijbel Gods rechtvaardigheid, barmhartigheid en liefde. De vragen van de theodicee kan men m.i. niet beantwoorden vanuit de natuur met zijn grootheid en schoonheid, maar ook zijn onverschilligheid voor wat aardverschuivingen, overstromingen en de voedselketen aanrichten (Flew 1971:13). Zodra het over het volle, echte leven gaat, zal de christelijke theologie dus over kruis en opstanding spreken. Zoals de theologie naar de ruimere verbanden vraagt waarin de natuur en evolutie staan, zo staat ook het spreken over de Schepper op grond van de natuur binnen de ruimere verbanden van het gehele bijbelse spreken over God. Met deze modificaties deel ik de spreuk "begin in het midden": het spreken over God vanuit de schepping krijgt een plaats binnen het omvattender spreken over God. Juist het denken over de natuurwetten en de geheimnisvolle ontwikkeling van de soorten maakt bescheiden: "Waar waart Gij, toen Ik de aarde grondvestte? Vertel het, indien gij inzicht hebt!” (Job 38:4).

\subsection{Het onkruid in de schepping}

We hebben gezien dat de idee van een "Designer" soms wordt afgewezen vanwege het probleem van het kwaad. Men kan ook op levende wezens wijzen die ongeschikt voor het leven waren en weer 
snel zijn uitgestorven. Ik heb erop gewezen dat uit "Design" niet zonder meer volgt dat de "Designer" goed en rechtvaardig is. Maar laat ik hier nog enkele overwegingen over God en het kwaad geven. In de godsdienstwijsgerige discussies over God en het kwaad in de schepping circuleerde een aantal decennia gelden een verhaal van een Engels filosoof John Wisdom (1945/6:191vv.). Het gaat om een Designer, of hij zijn schepping wel bijhoudt en of hij wel echt bestaat. Twee ontdekkingsreizigers kwamen op een open plek in het oerwoud. Ze zagen er veel bloemen en ook veel onkruid. De één zei: er moet een tuinman zijn die de bloembedden verzorgt. De ander was het er niet mee eens: ik geloof niet dat er een tuinman is. Ze zien hetzelfde, maar de één denkt dat er een tuinman is en de ander gelooft het niet. Anthony Flew ontwikkelde de gelijkenis enkele stappen verder. Ze slaan hun tent op en houden de wacht. Maar hoelang ze ook wachten, een tuinman zien ze niet. "Misschien is het een onzichtbare tuinman." Ze maken een omheining en later sluiten ze schrikdraad aan. Ze patrouilleren met bloedhonden. Maar er is geen enkel teken van een onzichtbare tuinman. Nog is de Gelovige niet overtuigd. "Maar er is echt een tuinman, onzichtbaar, je kunt hem niet aanraken, ongevoelig voor electrische schokken, zonder geur en geluid- en hij komt in het geheim en zorgt voor de tuin die hij liefheeft.” Anthony Flew zegt dat een dergelijke strategie om allerlei kwalificaties aan Gods eigenschappen toe te voegen die Hem onnaspeurbaar maken, ertoe bijdraagt dat het spreken over God ten onder gaat in "the death of a thousand qualifications"-wat zowel een fout in de logica inhoudt als in geloof. Men beweert eigenlijk niks meer (1971:22).

Discussies over 'intelligent design' en Schepping en Evolutie worden belast met de problemen van het kwaad: aardbevingen, overstromingen, misbaksels in de evolutie en wildgroei van onkruid en bacteriën. Wat “intelligent design”? Wat voor "Designer”? Wordt hier een onzichtbare hand ingevoerd van Iemand die we niet kunnen narekenen en wellicht niet kunnen vertrouwen? De vragen over God en het kwaad zijn echte vragen. Iets anders is of men ze mag opwerpen om de erkenning van orde in de structuur van de natuur te ontkennen. Mag men de toenemende complexiteit in de evolutie en het ontstaan van mensen met zelf-bewustzijn, taal en symbolisch vermogen terzijde laten als men over het eigene van de mens spreekt in onderscheiding van dieren? Ik denk dat men zich er te 
gemakkelijk vanaf maakt als men de wereld niet als langer ervaart als gemaakt met een bedoeling.

In de gelijkenis van het onkruid in het bloemenbed zoals Anthony Flew die verder ontwikkelde - ver buiten wat John Wisdom deed-vallen een aantal logische fouten op. De eerste fout is dat de tuinman als een mens wordt voorgesteld, die dan onzichtbaar wordt, onaanraakbaar en reukloos. Het kwalitatieve onderscheid tussen de Eeuwige en de mens verdwijnt zo uit het zicht, en al doende is de God die afgewezen wordt als onbewijsbaar veranderd in een raar soort mens. Dat is pas onto-theologie: God als een zijnde in de wereld. De gelijkenis berust te sterk op projectie. De tweede fout is dat Flew de rationaliteit die in empirisch onderzoek toegepast wordt, via deze "analogie" beslissend wil maken in de godsleer. Wisdom's (1945/6:194vv.) punt is juist dat het geen experimenteel verschil mening is maar dat geloof in God veel breder in menselijke ervaring is verankerd. De derde fout bij Flew is dat aan God gedrag van tuinlieden wordt toegeschreven: Een verstandige God wiedt onkruid. Dat het blijft staan, bewijst dat er geen tuinman, geen "god" zorgt voor de tuin en er dus helemaal niet is. De redenering die in deze gelijkenis wordt verondersteld deugt niet. De transcendentie van God en het mysterie van zijn bestaan zijn niet goed verwoord.

De vraag naar het onkruid in de akker heeft mensen al eeuwen bezig gehouden. Dat geldt zeker ook van de christelijke traditie. Wisdom's gelijkenis staat bedoeld of onbedoeld in de tekstgeschiedenis van een gelijkenis die Jezus zelf heeft verteld. "Het is met het koninkrijk van de hemel als met een mens die goed zaad op zijn akker uitzaaide. Terwijl de mensen sliepen, kwam zijn vijand onkruid tussen het graan zaaien en vertrok weer. Toen het jonge gewas opschoot en vrucht begon te dragen, kwam ook het onkruid te voorschijn. De knechten kwamen de heer des huizes vragen: "Heer, hebt u soms geen goed zaad op uw akker gezaaid? Waar komt dat onkruid vandaan?” Hij antwoordde: "Dat is het werk van een vijand." De knechten zeiden tegen hem: "Wilt u dat wij er het onkruid tussenuit wieden?" Hij antwoordde: 'Nee, want dan zouden jullie met het onkruid ook het graan lostrekken. laat beide samen opgroeien tot de oogst, dan zal ik, wanneer het oogsttijd is, tegen de maaier zeggen: "Wied eerst het onkruid, bind het in bundels bij elkaar en verbrand het. Breng het graan bijeen in mij schuur" (Matt 13:24-30; vss. 36-43. In deze gelijkenis zijn zaad en onkruid mensen, de kinderen van het koninkrijk en de kinderen van het 
kwaad. Maar als we de betekenis ervan oprekken en toepassen op goede en kwade dagen en fijne en nare dingen in de wereld, dan blijft het antwoord dat God besloten heeft het onkruid tussen de bloemen te laten staan. Misschien klinkt er zelfs in door dat het kwaad niet uit te roeien is zonder het goede kapot te maken. We moeten ook het goede niet verwarren met wat ons goed bevalt. In het licht van het koninkrijk van de hemel gelden er niet dezelfde maatstaven als in deze wereld gebruikelijk zijn.

De conclusie van dit hoofdstuk is dat de orde in de natuur en de toenemende complexiteit van de levende wezens en zelfbewustzijn van de mens niet afdoende causaal verklaarbaar zijn. Daaruit volgt dat de (wijsgerige) gedachte van Intelligent Design redelijk is; in die godsidee liggen een aantal eigenschappen van God besloten, maar niet noodzakelijkerwijs dat God goed en rechtvaardig is. De theodicee-vraag rijst pas bij geloof in de liefde en goedheid van God. Maar dat geloof berust op andere ervaringen dan die aanleiding zijn om van "intelligent design" te spreken.

\section{Literatuurverwijzingen}

Beker, E J, en Deurloo, K 1977. Het begin in ons midden. Aspecten van bijbels scheppingsgeloof. Baarn: Ten Have.

Davies, P 1993. The Mind of God, London: Penguin Books.

-, 1998. "Is het universum absurd?”. In de marge 7.

De Boer, T 1989. De god van de filosofen en de God van Pascal. Den Haag: Meinema.

De Groot, M 2005. "Het heelal en het leven; op maat gemaakt?”, in: Dekker, C e.a. (red.), Schitterend ongeluk, 190-193.

Dekker, C; Meester, R en Van Woudenberg, R 2005. Schitterend ongeluk of sporen van ontwerp? Over toeval en doelgerichtheid in de evolutie. Baarn: Ten Have.

Dembski, W A 1999. Intelligent Design. Downers Grove: InterVarsity Press.

Dippel, C J en De Jong, J M 1965-7. Geloof en Natuurwetenschap. 2 delen. Den Haag: Boekencentrum.

Flew, A a.o. 1971. “Theology and Falsification. A Symposium”, in: Mitchell, B (ed.). The Philosophy of Religion. Oxford: OUP.

Heidegger, M 1967. Wegmarken. Frankfurt a.M: Klostermann.

-, 1957 Identitätund Differenz. Pfullingen: Neske.

Lever, J 1958. Creatie en Evolutie. Wageningen: Zomer en Keunings, 2e druk.

Nishida, K 1990. Inquiry into the Good. Transl. by Masao Abe and Chr. Ives. London: Yale University Press. 
Middleton, R 2005. The Liberating Image. The imago dei in Genesis 1. Eugene (Oregon): Wipf \& Stock.

Susenbach, J S 2005. "Celdeling en de synthese van DNA; evolutie of ontwerp?”, in: Dekker, C e.a. (red.) 2005. e.a. Schitterend ongeluk, 134-143.

Van Aquino, T Summa Contra Gentiles, Book I.7.

Van Huyssteen, W 2006. Alone in the World? Human Uniqueness in Science and Theology. Grand Rapids: Eerdmans.

Van Woudenberg, R 2002. Ontwerp en toeval in de wereld. Amstelveen: de Zaak Haes. Inaugurele oratie.

Vroom, H M 2007. "Echt gebeurd? Verhalen of feiten? Over historische en literaire bijbelkritiek en de zeggenschap van de bijbel”. Verbum et Ecclesia 28(1) 2007, 345-371.

Wintermans, S 2005. "Over fotosynthese, evolutie en ontwerp; God en wetenschap”, in: Dekker, C e.a. (red.) 2005. Schitterend ongeluk.

Wisdom, J 1945-6. "Gods", Proceedings of the Aristotelian Society 46, 185206. 